\title{
Hemolysis of "Stress" Reticulocytes:
}

\section{a Source of Erythropoietic Bilirubin Formation}

\author{
Stephen H. Robinson and Maria Tsong \\ From the Departments of Medicine, Beth Israel Hospital and Harvard \\ Medical School, Boston, Massachusetts 02215
}

\begin{abstract}
A в S T R A C T The formation of bilirubin ${ }^{14} \mathrm{C}$ was measured in rats given transfusions of red blood cells containing ${ }^{14} \mathrm{C}$-labeled hemoglobin heme. Per cent conversion of hemoglobin ${ }^{14} \mathrm{C}$ to bilirubin was 4 times greater with transfusion of "stress" reticulocytes from rats responding to hemorrhage than with normal reticulocytes from unstimulated donors. When the increased number of labeled reticulocytes produced by hemorrhaged donors was also considered, the total magnitude of labeled bilirubin formation was almost 20 times higher with stress as compared to normal reticulocytes. The findings were not influenced by splenectomy of either donor or recipient rats, iron loading of donors, or bleeding of recipients. However, bilirubin $-{ }^{14} \mathrm{C}$ formation fell off progressively as studies were performed at longer intervals after erythroid stimulation.

Total bilirubin $-{ }^{14} \mathrm{C}$ formation in rats transfused with stress reticulocytes was compared to the production of early-labeled bilirubin from all potential sources in intact rats bled according to the same schedule used in the transfusion experiments. It is estimated that degradation of hemoglobin from sress reticulocytes accounts for virtually the entire rise in erythropoietic bilirubin formation from 24 to $96 \mathrm{hr}$ after glycine- $2-{ }^{14} \mathrm{C}$ administration, but that additional sources make a major contribution before that time. These findings are consistent with the concept that destruction of immature erythroid cells in the peripheral blood, and probably in the bone marrow, accompanies the physiologic response to erythroid stimulation.
\end{abstract}

\section{INTRODUCTION}

A small, but significant, fraction of bile pigment is derived from sources other than the hemoglobin of senes-

Part of this work has been published in abstract form, and was presented at the annual meeting of the American Federation for Clinical Research, Atlantic City, N. J., May $1968(1,2)$.

Received for publication 10 November $1969^{\circ}$ and in revised form 30 December 1969. cent red blood cells $(3,4)$. This early-labeled pigment fraction is observed within the first few days after the administration of a labeled heme precursor such as glycine-2 ${ }^{14} \mathrm{C}$, when labeled erythrocytes are just beginning to enter the peripheral blood $(3,4)$. Recent studies have shown that the early pigment fraction is heterogeneous in origin and consists of an initial sharp peak followed by a more prolonged second component (5-8). The initial peak appears to be derived exclusively from extra-erythroid sources $(6,7)$, primarily from the turnover of nonhemoglobin hemes in the liver (9-12). In rats the later or plateau component also is largely independent of erythroid sources under normal conditions (7), but contains a small erythropoietic component which is substantially augmented when red cell production is either accelerated or abnormal (7). It has been suggested that the erythropoietic fraction normally has a larger role in other species (13-15).

Several mechanisms have been proposed for the erythropoietic phase of bile pigment production (16), but none of these has been susceptible to direct experimental verification. A variety of associated findings suggest that ineffective erythropoiesis, i.e. destruction of immature erythroid cells within or soon after release from the bone marrow (17), accounts for the increase in early-labeled bilirubin production in certain hematologic diseases $(14,15,18-21)$. However, the applicability of this mechanism to physiologically regulated erythropoiesis has remained unclear. The present experiments were designed to evaluate whether increased early bilirubin production in animals responding to hemorrhage (7) might be due in part to hemolysis of immature erythroid cells in the peripheral blood, i.e., to "ineffective reticulocytosis."

\section{METHODS}

Experiments were performed in male Sprague-Dawley rats from a cesarian-derived, Bartonella-free colony. ${ }^{1}$ Animals weighed $300-400 \mathrm{~g}$.

${ }^{1}$ Charles River Breeding Labs, Inc., Wilmington, Mass. 


\section{Early-labeled bilirubin formation in intact rats}

The production of early-labeled bilirubin and hemoglobin heme was measured in rats with external bile drainage according to previously described techniques (7). Bile duct cannulation was performed under ether anesthesia, and 2-3 hr later the rats received $50 \mu \mathrm{Ci}$ glycine $-2-{ }^{14} \mathrm{C}^{2}$ intravenously. The total biliary excretion of bilirubin $-{ }^{14} \mathrm{C}$ was assessed at frequent intervals over the next 4 days from the specific activity of twice recrystallized bilirubin $(7,22)$ and the rate of total pigment excretion. Cardiac blood was withdrawn at the end of the experiment at $96 \mathrm{hr}$ for isolation and radioassay of hemoglobin hemin $(7,23,24)$; earlier studies have shown that labeling of hemoglobin by glycine $-{ }^{14} \mathrm{C}$ is maximal at 3-4 days in the rat (7).

Measurements were made in 10 normal rats, six rats in which $35 \%$ of estimated blood volume (25) had been removed by cardiac puncture 66 and again $20 \mathrm{hr}$ before the administration of glycine $-{ }^{14} \mathrm{C}$, and six rats that had been bled according to the same schedule but had also undergone splenectomy at the time of bile duct cannulation. Imprints of the cut surfaces of spleens from hemorrhaged and normal rats were stained with Wright's stain and examined microscopically for the presence of red cell precursors.

Labeled bilirubin production was expressed as disintegrations per minute (dpm) in bilirubin $-{ }^{14} \mathrm{C}$ excreted per hour during each interval of bile collection. Values were plotted at the median times of each collection period and smooth curves were drawn through these points. In addition, the per cent of administered glycine $-{ }^{14} \mathrm{C}$ incorporated into earlylabeled bilirubin was calculated for two broad intervals, $0-3.5$ and 3.5-96 hr after isotope injection. These somewhat arbitrary division conform to the initial sharp peak and the plateau phase of early pigment formation in the rat (7). The limit of the late phase was set at $96 \mathrm{hr}$, rather than $60 \mathrm{hr}$ as in previous studies (7), because of the prolongation of this component observed in several of the bled rats and for ease of comparison with the transfusion experiments. Production of labeled hemoglobin heme was expressed as per cent incorporation of glycine $-{ }^{14} \mathrm{C}$, calculated from the specific activity of hemoglobin hemin and the hemin equivalent of the rat's blood volume (25). It was assumed that in anemic rats blood volume decreased $5 \%$ for each $10 \%$ fall in hemoglobin concentration $(26,27)$.

\section{Conversion of reticulocyte hemoglobin heme- ${ }^{14} \mathrm{C}$ to bilirubin- ${ }^{14} \mathrm{C}$}

Preparation of labeled cells for transfusion into rats with external bile drainage. Except as noted, reticulocytosis was induced by removal of $35 \%$ blood volume by cardiac puncture 66 and again $20 \mathrm{hr}$ before the intravenous injection of $100 \mu \mathrm{Ci}$ glycine- $2-{ }^{14} \mathrm{C}$, the same schedule used to stimulate increased early bilirubin production in intact rats. $24 \mathrm{hr}$ later the animals were exsanguinated to yield "stress" reticulocytes containing ${ }^{14} \mathrm{C}$-labeled hemoglobin heme. Labeled normal reticulocytes were obtained from rats which had not been bled but received $100 \mu \mathrm{Ci}$ glycine- ${ }^{14} \mathrm{C} 24 \mathrm{hr}$ before exsanguination. Labeled adult red blood cells were derived from normal rats given $100 \mu \mathrm{Ci}$ glycine $-{ }^{14} \mathrm{C} 10$ days earlier.

Cardiac blood was collected in plastic syringes containing $2 \mathrm{ml}$ acid citrate dextrose (ACD) solution $^{3}$ per $10 \mathrm{ml}$ of

\footnotetext{
${ }^{2}$ Glycine-2 ${ }^{14} \mathrm{C}, 18 \mathrm{mCi} / \mathrm{mmole}$, New England Nuclear Corp., Boston, Mass.

${ }^{3}$ USP Formula A, Fenwall Laboratories, Inc., Morton Grove, Ill.
}

blood. In most experiments blood from two to four donor rats was combined for transfusion into two recipient animals. The hematocrit, hemoglobin concentration, and reticulocyte percentage of the combined donor bloods were measured (28), and a sample was removed for crystallization and radioassay of hemoglobin heme- ${ }^{14} \mathrm{C}(7,23,24)$. In early experiments all preparative procedures were performed with either plastic or siliconized glass containers, but later identical results were obtained with the use of standard glassware. All manipulations were carried out at $4^{\circ} \mathrm{C}$. In order to reduce manipulations in vitro to a minimum, no attempt was made to separate reticulocytes from older cells. The pooled donor blood was divided into portions for each recipient rat, and excess plasma was removed after centrifugation for $15 \mathrm{~min}$ at $1200 \mathrm{rpm}$ in a PR2-International Centrifuge. After the addition of $30 \mathrm{mg}$ of nonradioactive glycine in $1.0-1.5 \mathrm{ml}$ of physiologic saline, the volume and hemoglobin concentration of the final transfusion mixture were measured. The blood was then injected over 3-5 min into the tail vein of a recipient rat in which the common bile duct had been cannulated with polyethylene tubing ${ }^{4} 18 \mathrm{hr}$ earlier. Unless otherwise specified, recipient animals received transfusions containing $0.7-1.0 \mathrm{~g}$ of hemoglobin. The radioactive dose (dpm in transfused hemoglobin heme- ${ }^{14} \mathrm{C}$ ) was calculated from the hemoglobin content and hemin specific activity of the donor blood.

Bilirubin ${ }^{14} \mathrm{C}$ excretion in recipient rats. After the transfusion, bile samples were collected in the dark over ice at $3.5,24,48,72$, and occasionally also 96 and $120 \mathrm{hr}$. The volume and bilirubin concentration (29) of each sample were measured. Bilirubin was then crystallized from the bile $(7,22)$, twice recrystallized, and its specific activity measured in a liquid scintillation spectrometer ${ }^{5}(7,22)$. Counting efficiency was determined by automatic external standardization with a ${ }^{183} \mathrm{Ba}$ source.

The rate of production of bilirubin- ${ }^{14} \mathrm{C}$ (dpm in bilirubin${ }^{14} \mathrm{C}$ excreted per hour) during each collection period was calculated from the specific activity of bilirubin $-{ }^{14} \mathrm{C}$ and the rate of total bilirubin excretion during that interval. These data are presented in two ways. (a) Per cent conversion of hemoglobin heme $-{ }^{14} \mathrm{C}$ in transfused red cells to bilirubin $-{ }^{14} \mathrm{C}$ was calculated, with correction for the loss of one-eighth the number of glycine-labeled carbon atoms in heme during degradation to bile pigment (22). (b) To estimate the total magnitude of bilirubin- ${ }^{14} \mathrm{C}$ production and to correct for variations in the amount of blood transfused in each experiment, the observed rates of labeled pigment excretion were adjusted to correspond to transfusions of an entire donor red cell mass. The average donor blood volume was calculated from the body weights of the donors used in each experiment $(25)$, with correction for anemia $(26,27)$ as appropriate. The observed rates of bilirubin $-{ }^{14} \mathrm{C}$ production in the recipients of this donor blood were then multiplied by the ratio between total donor hemoglobin and the amount of hemoglobin actually transfused. These figures permitted estimation of the per cent incorporation of the glycine $-{ }^{14} \mathrm{C}$ originally given to the donors into bilirubin $-{ }^{14} \mathrm{C}$ excreted by recipients of labeled donor cells.

Conditions affecting bilirubin- ${ }^{14} \mathrm{C}$ production. The effect of the number of stress reticulocytes transfused upon the conversion of reticulocyte hemoglobin $-{ }^{14} \mathrm{C}$ to bilirubin $-{ }^{14} \mathrm{C}$ was evaluated in three rats, which received transfusions containing $0.11,0.53$, and $0.93 \mathrm{~g}$ of hemoglobin respectively. All

${ }^{4}$ PE50, Clay-Adams, Inc., New York.

${ }^{5}$ Model Mark I liquid scintillation spectrometer, NuclearChicago Corp., Des Plaines, Ill. 
of the transfused bloods were derived from the same pool of donor cells.

The role of the spleen was evaluated in experiments in which donor and(or) recipient rats were subjected to splenectomy (see Table III). Splenectomy or sham-splenectomy was performed 8-10 days before glycine $-{ }^{14} \mathrm{C}$ administration in donor rats. Recipients underwent splenectomy at the time of bile duct cannulation.

In some experiments the schedule of bleeding donor rats was varied (see Fig. 2) in order to assess the relationship of reticulocyte hemolysis to the phase of the reticulocyte response to hemorrhage.

In one experiment donor rats were given iron-dextran, ${ }^{6} 5$ mg intramuscularly, 4 and 2 days before the first bleeding and on the days of both the first and second bleedings. Bilirubin- ${ }^{14} \mathrm{C}$ production was then measured in two rats transfused with blood from these donors.

To determine whether hemorrhage might induce extracorpuscular changes conducive to reticulocyte hemolysis, six recipient rats were bled according to the same schedule used to prepare donors of stress reticulocytes. Four of these animals received transfusions of labeled stress reticulocytes and two were given labeled normal reticulocytes.

\section{Disappearance of ${ }^{50} \mathrm{Fe}-$ labeled reticulocytes}

Donor rats were prepared as in the previous experiments, but $25 \mu \mathrm{Ci}{ }^{50} \mathrm{Fe}$ citrate ${ }^{7}$ was given intravenously instead of glycine $-{ }^{14} \mathrm{C}$. Recipients underwent splenectomy or shamsplenectomy 4-5 days before transfusion but were not subjected to bile duct cannulation. In order to minimize reutilization of ${ }^{60} \mathrm{Fe}$, each recipient received intramuscular injections of $5 \mathrm{mg}$ of iron-dextran 2 days, 1 day, and $1 \mathrm{hr}$ before transfusion, and also on the 1 st and 2 nd days after transfusion.

Cells for transfusion were prepared as in the experiments with glycine- ${ }^{14} \mathrm{C}$ except that the nonradioactive glycine was omitted. The recipients were given small transfusions, equivalent to $0.15-0.22 \mathrm{~g}$ of hemoglobin, in order to minimize alterations in the steady state of erythropoiesis; hematocrits remained stable throughout the subsequent 3 days of observation. $0.4 \mathrm{ml}$ samples of blood were collected from a tail vein in heparin-wet syringes at $15 \mathrm{~min}$ and at $3.5,24,48$, and $72 \mathrm{hr}$ for measurement of hematocrit, hemoglobin concentration, and ${ }^{50} \mathrm{Fe}$ specific activity. At the end of each experiment the animal was sacrificed, and the spleen, liver, and kidneys were removed for radioassay.

All radioactive measurements were performed in a welltype gamma scintillation spectrometer. ${ }^{8}$ Blood samples were hemolyzed with a drop of $\mathrm{NH}_{4} \mathrm{OH}$. Counts per minute (cpm) per milliliter of packed red cells were calculated from the specific activities of whole blood and plasma on the basis of hematocrit. Specific activities in each experiment were expressed as per cent of the initial value measured at $15 \mathrm{~min}$.

The entire spleen, one kidney, and a portion of the liver were minced, digested with concentrated $\mathrm{HCl}$, and their content of radioactivity measured. Total radioactivity recovered in each organ was expressed as per cent of the ${ }^{50} \mathrm{Fe}$ originally transfused. The contribution of circulating red cells to organ ${ }^{50} \mathrm{Fe}$ radioactivity was also measured in three rats just before the experiments were terminated at $72 \mathrm{hr}$.

\footnotetext{
${ }^{6}$ Imferon, Lakeside Laboratories, Inc., Milwaukee, Wis.

${ }^{7}$ Ferrous citrate ${ }^{50} \mathrm{Fe}, 16.5 \mathrm{mCi} / \mathrm{mg}$, Abbott Laboratories, North Chicago, Ill.

${ }^{8}$ Model 4218, Nuclear-Chicago Corp., Des Plaines, Ill.
}

$0.5 \mathrm{ml}$ of a suspension of normal rat erythrocytes labeled with ${ }^{51} \mathrm{Cr}^{9}$ (25) was injected into the tail vein $15 \mathrm{~min}$ before sacrifice. Excised organs were assayed for both ${ }^{51} \mathrm{Cr}$ and ${ }^{50} \mathrm{Fe}$ radioactivity. The average recovery of injected ${ }^{51} \mathrm{Cr}$ was $1.1 \%$ in spleen, $5.2 \%$ in liver, and $0.7 \%$ in both kidneys. The organ content of circulating ${ }^{50} \mathrm{Fe}$-labeled cells was calculated from these values by correcting for the decline in ${ }^{50} \mathrm{Fe}$ red cell specific activity during the $72 \mathrm{hr}$ since transfusion.

\section{RESULTS}

Early-labeled bilirubin formation in intact rats. The average excretion of bilirubin in bile was only moderately depressed in the bled as compared to the normal animals, when calculated on the basis of body weight (Table I). Calculated per gram of circulating hemoglobin, total bilirubin production was approximately twice the control value. Although there was as much as a twofold rise in the formation of early-labeled bilirubin in the bled rats (Table I), the early fraction normally comprises only $10-20 \%$ of total pigment production $(3$, $4,7)$ and this degree of elevation is insufficient to explain the observed increase in bile bilirubin excretion. It is probable that the latter is misleadingly high and was derived in part from pericardial hematomas resulting from the previous cardiac punctures.

As reported earlier (7), hemorrhage led to an increase in the later, plateau phase of the early-labeled peak (Fig. 1, Table I). However, there was also a rise in the initial sharp component. Thus, the shape of the "hemorrhage" curve remained similar to that in controls, except for a small "shoulder" early in the plateau phase. In rats subjected to hemorrhage and then splenectomy, the height of the plateau phase was intermediate between that of bled and control animals, whereas the elevation of the initial peak was not significantly different from that in animals subjected to hemorrhage alone.

Glycine ${ }^{-14} \mathrm{C}$ incorporation into hemoglobin heme increased to a greater extent in bled animals with intact spleens than in their splenectomized counterparts (Table I). This corresponds to the findings for the plateau component of early-labeled bilirubin; thus, the ratio of isotope incorporation into late phase bilirubin- ${ }^{14} \mathrm{C}$ compared to hemoglobin heme- ${ }^{14} \mathrm{C}$ was similar in all three experimental groups (Table I). Normoblasts were readily discernible in imprints from the excised spleens of hemorrhaged but not of normal animals.

Conversion of reticulocyte hemoglobin heme ${ }^{14} \mathrm{C}$ to bilirubin ${ }^{14} C$. In recipients of "stress" reticulocytes from bled donors, an average of $6.5 \%$ of transfused hemoglobin heme- ${ }^{14} \mathrm{C}$ was excreted as bilirubin ${ }^{14} \mathrm{C}$ in the bile over the 3 days of observation (Table II). By contrast, only $1.6 \%$ conversion was found in animals

\footnotetext{
Dodium chromate ${ }^{51} \mathrm{Cr}$ injection, $125-550 \mathrm{mCi} / \mathrm{mg}$ of $\mathrm{Cr}$, Abbott Laboratories, North Chicago, I1l.
} 
TABLE I

Production of Early-Labeled Bilirubin and Hemoglobin Heme from Glycine-2-14C in Rats with External Bile Drainage

\begin{tabular}{|c|c|c|c|c|c|c|c|}
\hline \multirow[b]{3}{*}{ Condition } & \multirow[b]{3}{*}{ Hemoglobin* } & & & \multicolumn{4}{|c|}{ Per cent glycine- ${ }^{14} \mathrm{C}$ incorporation } \\
\hline & & \multirow{2}{*}{\multicolumn{2}{|c|}{ Bile bilirubin excretion }} & \multicolumn{2}{|c|}{ Early-labeled bilirubin } & \multirow{2}{*}{$\begin{array}{c}\text { Hemoglobin } \\
\text { heme } \\
(96 \mathrm{hr})\end{array}$} & \multirow{2}{*}{$\begin{array}{c}\text { Ratio late } \\
\text { phase } \\
\text { bilirubin-14C: } \\
\text { Hb heme-14 }\end{array}$} \\
\hline & & & & $\begin{array}{l}\text { Early phase } \\
(0-3.5 \mathrm{hr})\end{array}$ & $\begin{array}{l}\text { Late phase } \\
(3.5-96 \mathrm{hr})\end{array}$ & & \\
\hline & $\mathrm{g} / 100 \mathrm{ml}$ & $\begin{array}{c}\mu g / h r \text { per } 100 \mathrm{~g} \\
\text { body } w t\end{array}$ & $\begin{array}{c}\mu g / h r \text { per } g \\
\text { circulating } H b \ddagger\end{array}$ & \multicolumn{4}{|c|}{$\%$} \\
\hline $\begin{array}{l}\text { Normal, } \\
10 \text { rats }\end{array}$ & $14.9 \pm 0.3$ & $29.0 \pm 2.0$ & $33.2 \pm 1.8$ & $0.015 \pm 0.001$ & $0.092 \pm 0.003$ & $0.38 \pm 0.12$ & 0.24 \\
\hline $\begin{array}{l}\text { Hemorrhage, } \\
6 \text { rats }\end{array}$ & $7.9 \pm 0.3$ & $23.8 \pm 0.8$ & $71.0 \pm 3.4$ & $0.020 \pm 0.003$ & $0.226 \pm 0.018$ & $0.86 \pm 0.07$ & 0.26 \\
\hline $\begin{array}{l}\text { Hemorrhage } \\
\text { splenectom }\end{array}$ & & & & & & & \\
\hline 6 rats & $7.8 \pm 0.3$ & $22.7 \pm 0.9$ & $68.6 \pm 2.8$ & $0.022 \pm 0.003$ & $0.154 \pm 0.014$ & $0.66 \pm 0.10$ & 0.23 \\
\hline
\end{tabular}

Means \pm SE (47) are shown.

* From tail blood sampled at the time of bile duct cannulation and splenectomy (the day after the last hemorrhage in bled rats).

$\ddagger$ Based on hemoglobin concentration and blood volume corrected for anemia (see Methods).

transfused with reticulocytes from normal donors. After transfusion of labeled adult erythrocytes, a mean of $2.5 \%$ was observed.

Fig. 2 illustrates the relationship between reticulocyte survival, as reflected in bilirubin $-{ }^{14} \mathrm{C}$ formation, and the phase of the reticulocyte response to hemorrhage. In general, labeled bilirubin production varied with the height of the reticulocytosis. Conversion of reticulocyte hemoglobin heme to bilirubin was maximal when donor rats were bled 4 and 2 days before the transfusions, when maximal reticulocytosis was observed; this was the schedule employed in most of the present experi- ments. As the interval between the hemorrhages and transfusion was widened, comparatively high reticulocyte counts were accompanied by progressively lower levels of bilirubin excretion. When bleedings were performed 7 and 5 days before transfusion, reticulocytes were still $14 \%$ but bilirubin $-{ }^{14} \mathrm{C}$ production had fallen to only $1.9 \%$, as compared to $1.6 \%$ with normal reticulocytes from rats that had not been bled.

A variety of experimental conditions failed to alter bilirubin $-{ }^{14} \mathrm{C}$ production in recipient animals (Table III). The survival of stress reticulocytes was unaffected by splenectomy of either donor or recipient rats. Similarly,

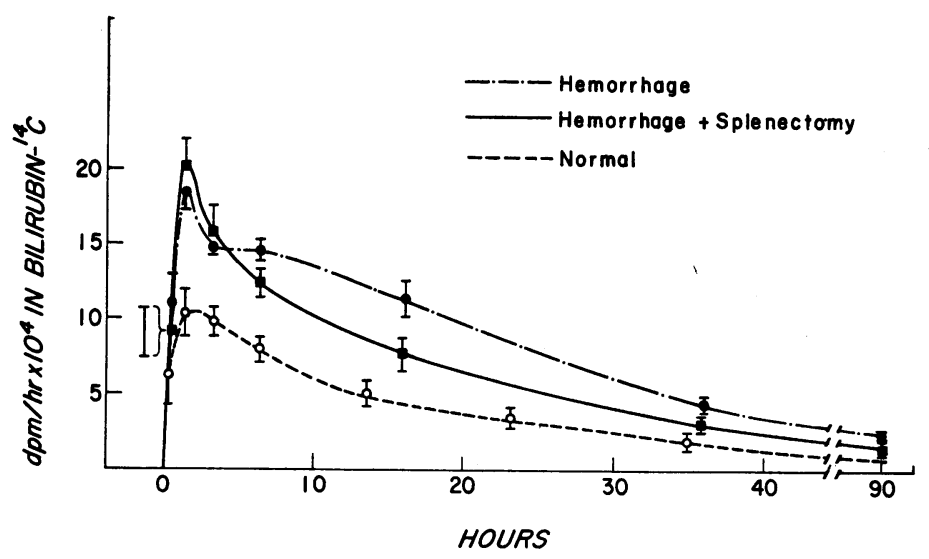

Figure 1 The production of early-labeled bilirubin in hemorrhaged rats. Splenectomy was performed at the time of bile duct cannulation, $2-3 \mathrm{hr}$ before the administration of glycine- $2-{ }^{14} \mathrm{C}$. The scale has been adjusted to correspond to a dose of $1 \mathrm{mCi}$ glycine $-{ }^{14} \mathrm{C}$. Means $\pm_{\mathrm{SE}}$ (47) are plotted. Because of overlap, only an upper or lower SE is shown for a few of the early points. 
TABLE II

Conversion of Hemoglobin Heme- ${ }^{14} \mathrm{C}$ in Transfused Cells to Bilirubin-14 C

\begin{tabular}{|c|c|c|c|c|c|c|c|}
\hline \multirow[b]{2}{*}{ Cell type } & \multirow[b]{2}{*}{$\begin{array}{c}\text { No. of } \\
\text { experiments* }\end{array}$} & \multicolumn{3}{|c|}{ Donor blood $\ddagger$} & \multicolumn{3}{|c|}{ Recipient bilirubin- ${ }^{14} \mathrm{C}$ excretion } \\
\hline & & Hemoglobin & Reticulocytes & $\begin{array}{c}\text { Glycine-14C } \\
\text { incorporation into } \\
\text { Hb heme-14C }\end{array}$ & $\begin{array}{l}\text { No. of } \\
\text { recipients }\end{array}$ & $\begin{array}{c}\text { Conversion of } \\
\text { transfused } \\
\text { Hb heme-14 C }\end{array}$ & $\begin{array}{l}\text { Glycine-14C } \\
\text { incorporation } \S\end{array}$ \\
\hline Stress & & $\mathrm{g} / 100 \mathrm{ml}$ & $\%$ & $\%$ & & $\%$ & $\%$ \\
\hline reticulocytes & 9 & $8.7 \pm 0.2$ & $21.5 \pm 1.7$ & $1.15 \pm 0.04$ & 21 & $6.5 \pm 0.4$ & $0.070 \pm 0.005$ \\
\hline $\begin{array}{l}\text { Normal } \\
\quad \text { reticulocytes }\end{array}$ & 3 & $13.6 \pm 0.5$ & $1.8 \pm 0.3$ & $0.29 \pm 0.06$ & 6 & $1.6 \pm 0.1$ & $0.004 \pm 0.001$ \\
\hline $\begin{array}{l}\text { Adult } \\
\quad \text { erythrocytes }\end{array}$ & 2 & $\begin{array}{l}13.3 \\
13.7\end{array}$ & $\begin{array}{l}2.2 \\
2.1\end{array}$ & $\begin{array}{l}0.62 \\
0.47\end{array}$ & 4 & $2.5 \pm 0.5$ & $0.009 \pm 0.001$ \\
\hline
\end{tabular}

Means \pm SE (47) are shown.

* In most experiments combined blood from two to four donors was transfused into two recipients.

¥ Heart blood at the time of exsanguination (2 days after the last hemorrhage in donors of stress cells).

$\S$ Based on assumed transfusion of entire red cell mass of the average donor in each experiment.

splenectomy did not affect the findings with normal reticulocytes or adult red cells, and the results of all of these experiments have therefore been pooled in Table II. Conversion of labeled hemoglobin to bilirubin was not related to the number of stress reticulocytes transfused, since similar results were observed with transfusion of eightfold different volumes of the same donor blood. The data in Table III also show that reticulocyte hemolysis was not altered by iron loading of donor rats, although it remains possible that such treatment may not have made sufficient iron available to rapidly proliferating erythroid cells. Bilirubin $-{ }^{14} \mathrm{C}$ production in bled recipients given either stress or normal reticulocytes was comparable to that in normal recipients, indicating that reticulocyte hemolysis is not conditioned by extracorpuscular factors. Finally, there was only negligible excretion of bilirubin $-{ }^{14} \mathrm{C}$ in two rats transfused with radioactive plasma from stress and normal reticulocyte blood respectively. Thus, the experimental results were not influenced by the production of early-labeled bilirubin from residual glycine $-{ }^{14} \mathrm{C}$ in the transfused plasma.

The kinetics and the magnitude of bilirubin $-{ }^{14} \mathrm{C}$ formation are shown in Fig. 3, in which the observed rates of bilirubin $-{ }^{14} \mathrm{C}$ excretion have been adjusted to correspond to transfusions of an entire donor red cell mass. The narrow range of glycine $-{ }^{14} \mathrm{C}$ incorporation into total donor hemoglobin heme (Table II) confirms the comparability of the donors within each of the three experimental groups. With transfusion of stress reticulocytes bilirubin- ${ }^{14} \mathrm{C}$ production was maximal during the second period of bile collection between 3.5 and $24 \mathrm{hr}$. Labeled pigment excretion then declined, but did not reach base line levels by $72 \mathrm{hr}$ when most of the experiments were terminated. Additional measurements were made in a few experiments, and bilirubin- ${ }^{14} \mathrm{C}$ production continued to fall off smoothly from $72 \mathrm{hr}$ to $120 \mathrm{hr}$.

The absolute magnitude of labeled bilirubin formation in rats transfused with stress reticulocytes was almost 20 times higher than in animals given normal reticulocytes (Fig. 3, Table II, last column). This exceeds the fourfold difference in per cent conversion of labeled hemoglobin heme to bilirubin- ${ }^{14} \mathrm{C}$ (Table II), since the latter reflects the hemolytic susceptibility of individual cells, but fails to account for the increased number of labeled reticulocytes in the blood of hemorrhaged donors.

It is now possible to compare (Fig. 4) the increment in early-labeled bilirubin production from all sources in

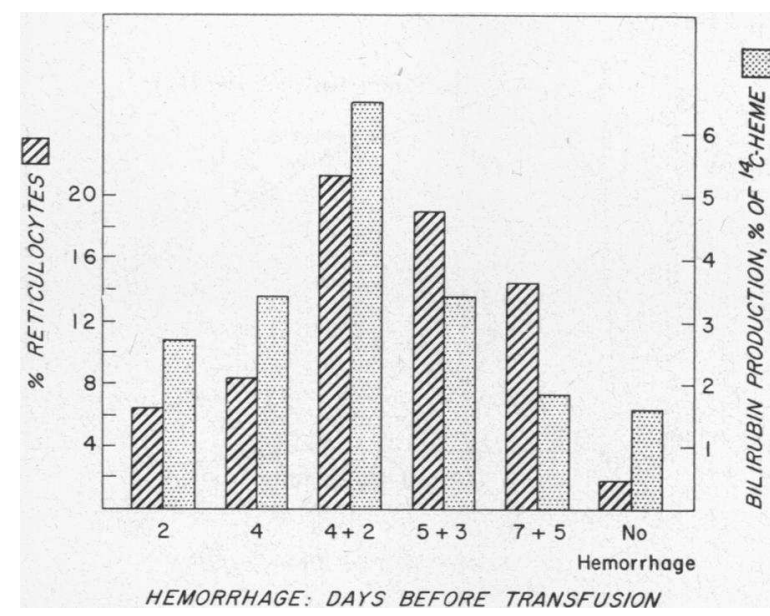

Figure 2 The relationship between per cent conversion of reticulocyte hemoglobin heme $-{ }^{14} \mathrm{C}$ to bilirubin $-{ }^{14} \mathrm{C}$ and the phase of the reticulocyte response to hemorrhage. Donor rats received glycine $-{ }^{14} \mathrm{C} 1$ day after the last hemorrhage, and their blood was used for transfusion 1 day later. 
TABLE III

Conversion of Reticulocyte Hemoglobin Heme-14 C to Bilirubin-14 $C$ under Different Conditions

\begin{tabular}{|c|c|c|c|}
\hline Cell type & $\begin{array}{l}\text { Special } \\
\text { conditions }\end{array}$ & $\begin{array}{l}\text { No. of } \\
\text { recipients }\end{array}$ & $\begin{array}{c}\% \text { Conversion } \\
\text { transfused } \\
\text { Hb heme-14C } \\
\text { to bilirubin-14C }\end{array}$ \\
\hline \multirow[t]{6}{*}{$\begin{array}{l}\text { Stress } \\
\quad \text { reticulocytes }\end{array}$} & $\begin{array}{c}\text { Splenectomy } \\
\text { (donors/recipients) }\end{array}$ & & \\
\hline & Sham/Sham & 4 & $6.0 \pm 1.1$ \\
\hline & Sham/Splenx & 7 & $5.8 \pm 1.5$ \\
\hline & Splenx/Sham & 7 & $6.4 \pm 1.8$ \\
\hline & Splenx/Splen $x$ & 3 & $7.1 \pm 1.5$ \\
\hline & Combined & 21 & $6.5 \pm 1.8$ \\
\hline \multirow[t]{4}{*}{$\begin{array}{l}\text { Stress } \\
\quad \text { reticulocytes }\end{array}$} & $\begin{array}{l}\text { Varying transfusion } \\
\text { doses }\end{array}$ & & \\
\hline & $0.93 \mathrm{~g} \mathrm{Hb}$ & 1 & 5.0 \\
\hline & $0.53 \mathrm{~g} \mathrm{Hb}$ & 1 & 7.7 \\
\hline & $0.11 \mathrm{~g} \mathrm{Hb}$ & 1 & 7.1 \\
\hline $\begin{array}{l}\text { Stress } \\
\quad \text { reticulocytes }\end{array}$ & Iron-treated donors & 2 & $5.6,8.6$ \\
\hline $\begin{array}{l}\text { Stress } \\
\quad \text { reticulocytes }\end{array}$ & Bled recipients & 4 & $6.8 \pm 0.9$ \\
\hline $\begin{array}{l}\text { Normal } \\
\text { reticulocytes }\end{array}$ & 一 & 6 & $1.6 \pm 0.2$ \\
\hline $\begin{array}{l}\text { Normal } \\
\text { reticulocytes }\end{array}$ & Bled recipients & 2 & $1.7,1.7$ \\
\hline
\end{tabular}

Means \pm SD (47) are shown.

intact bled rats (Fig. 1) with the total production of bilirubin- ${ }^{14} \mathrm{C}$ from hemolysis of stress reticulocytes, as estimated from the transfusion experiments (Fig. 3). It should be noted that in the latter experiments measurement of labeled bilirubin excretion was begun at the

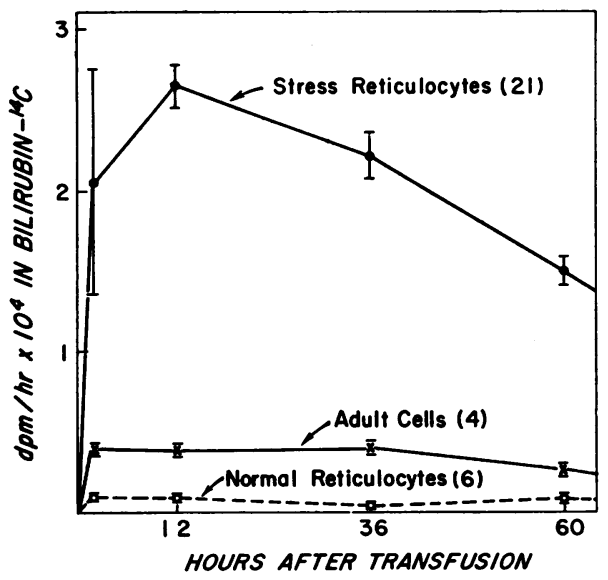

Figure 3 Total bilirubin- ${ }^{14} \mathrm{C}$ production in recipients of ${ }^{14} \mathrm{C}$-labeled red cells. The observed rates of bile bilirubin $-{ }^{14} \mathrm{C}$ excretion have been adjusted to correspond to transfusions of an entire donor red cell mass. Scale has been adjusted to a dose of $1 \mathrm{mCi}$ glycine- ${ }^{14} \mathrm{C}$ in donor rats. Means $\pm \mathrm{SE}$ are plotted. time of transfusion, $24 \mathrm{hr}$ after the donor rats had been injected with glycine- ${ }^{14} \mathrm{C}$. The 3 days during which bilirubin $-{ }^{14} \mathrm{C}$ production was measured in the transfusion experiments therefore conform to the $24-96 \mathrm{hr}$ portion of the early-labeled peak in intact rats. During this interval (Fig. $4 a$ ) the formation of early-labeled bilirubin rose $145 \times 10^{4} \mathrm{dpm}$ above the normal curve as the result of hemorrhage. Virtually the same figure $\left(144 \times 10^{4} \mathrm{dpm}\right)$ was found for total bilirubin $-{ }^{14} \mathrm{C}$ production from hemolysis of stress as compared to normal reticulocytes.

In two additional experiments, transfusions of stress reticulocytes were given 12 rather than $24 \mathrm{hr}$ after the donors had received glycine $-{ }^{14} \mathrm{C}$. Average bilirubin $-{ }^{14} \mathrm{C}$ excretion during the first $12 \mathrm{hr}$ of these experiments is plotted under the 12-24 $\mathrm{hr}$ segment of the early-labeled peak in intact animals (Fig. $4 b$ ). During this period reticulocyte hemolysis accounted for only about onethird of the total increment in early bilirubin production, $25.5 \times 10^{4}$ as compared to $83 \times 10^{4} \mathrm{dpm}$ in bilirubin ${ }^{14} \mathrm{C}$

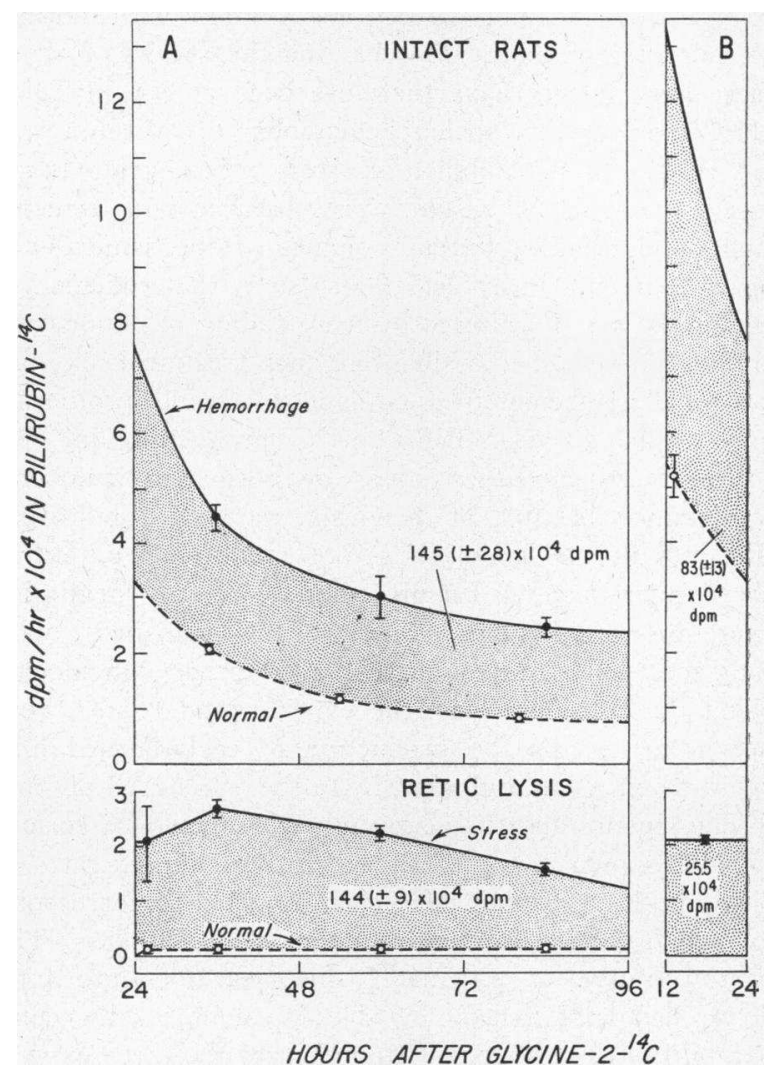

Figure 4 Comparison of the increment in early-labeled bilirubin formation in intact hemorrhaged rats (from Fig. 1) with total bilirubin- ${ }^{14} \mathrm{C}$ production in rats transfused with labeled stress as compared to normal reticulocytes (from Fig. 3). The lower portion of panel $B$ shows the average values in two rats given stress cells 12 rather than $24 \mathrm{hr}$ after the donors received glycine- ${ }^{14} \mathrm{C}$. 
respectively. Two factors account for this disparity. Labeling of donor hemoglobin heme- ${ }^{14} \mathrm{C}$ was lower when blood was harvested 12 rather than $24 \mathrm{hr}$ after glycine${ }^{14} \mathrm{C}$ administration; glycine- ${ }^{14} \mathrm{C}$ incorporation was $0.90 \%$ after $12 \mathrm{hr}$, compared to $1.15 \%$, sD 0.11 , after $24 \mathrm{hr}$ (Table II). However, since per cent conversion to bilirubin- ${ }^{14} \mathrm{C}$ during the first $12 \mathrm{hr}$ was similar in both sets of experiments $(1.37$ and $1.45 \%$ with blood collected at $12 \mathrm{hr}$ and a mean of $1.39 \%,{ }^{10} \mathrm{SD} 0.11$, with cells obtained at $24 \mathrm{hr}$ ), the rate of total bilirubin $-{ }^{14} \mathrm{C}$ formation was only moderately lower in the earlier than in the routine transfusion studies (Fig. 4, lower panels). More important, the rise in early-labeled bilirubin production in intact bled rats was proportionately much greater during the 12-24 hr interval than during the 24-96 hr interval (Figs. 1 and 4, upper panels). Therefore, mechanisms in addition to reticulocyte hemolysis appear to play a major role during the earlier phases of erythropoietic bilirubin production. Transfusion experiments were not performed before $12 \mathrm{hr}$, but it is assumed that these other mechanisms would have become relatively more important as measurements were made closer to the time of glycine- ${ }^{14} \mathrm{C}$ administration.

Disappearance of ${ }^{59} \mathrm{Fe}$-labeled reticulocytes. During the 3 days after transfusion of ${ }^{50} \mathrm{Fe}$-labeled stress reticulocytes, red cell specific activity fell an average of $12 \%$ below the initial value measured at $15 \mathrm{~min}$ (Fig. 5). The corresponding figure for normal reticulocytes was only $3.5 \%$. These values are approximately twice as large as the corresponding figures for per cent conversion of transfused hemoglobin heme $-{ }^{14} \mathrm{C}$ to bilirubin, i.e., $6.5 \%$ for stress reticulocytes and $1.6 \%$ for normal reticulocytes (Table II). As in the bilirubin $-{ }^{14} \mathrm{C}$ studies,

${ }^{10}$ This represents half of the 1st day's values since measurements were not made at $12 \mathrm{hr}$ during the routine transfusion experiments.

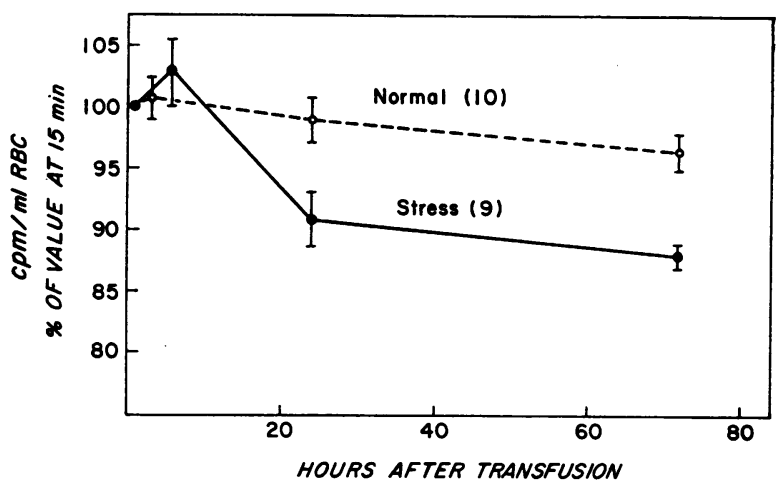

Figure 5 Disappearance of ${ }^{50} \mathrm{Fe}$-labeled reticulocytes in normal recipient rats. Means $\pm \mathrm{SE}$ are plotted.

splenectomy of either donor or recipient rats failed to alter the findings, and the data from all such experiments have therefore been combined.

The organ distribution of ${ }^{80} \mathrm{Fe}$ at the end of the experiments is shown in Table IV. Splenic radioactivity was consistently higher in recipients of stress reticulocytes as compared to normal cells. In splenectomized recipients of stress reticulocytes, the liver accounted for all of the radioactivity found in both the spleen and liver of recipients with intact spleens. Kidney radioactivity was small under all conditions. All of these relationships remained the same after correction for ${ }^{50} \mathrm{Fe}$-labeled blood in these organs at the time of sacrifice; a net of 4-5\% of transfused ${ }^{50} \mathrm{Fe}$ was recovered in these three organs in either splenectomized or sham-operated recipients of stress reticulocytes, whereas only $0-1 \%$ was recovered in recipients of normal reticulocytes.

\section{DISCUSSION}

This study provides direct evidence that the increase in early-labeled bilirubin formation found with ac-

TABLE IV

Recovery of Transfused Reticulocyte- ${ }^{59} \mathrm{Fe}$ in Organs of Recipient Rats

\begin{tabular}{|c|c|c|c|c|c|}
\hline \multirow[b]{2}{*}{ Cell type } & \multirow{2}{*}{$\begin{array}{l}\text { Condition of } \\
\text { recipients }\end{array}$} & \multirow{2}{*}{$\begin{array}{l}\text { No. of } \\
\text { recipients }\end{array}$} & \multicolumn{3}{|c|}{ \% Recovery of Transfused ${ }^{59} \mathrm{Fe}^{*}$} \\
\hline & & & Spleen & Liver & $\overline{\text { Kidneys }}$ \\
\hline Stress reticulocytes & Sham-splenectomy & 6 & $\begin{array}{l}3.3 \pm 0.5 \\
(2.3)\end{array}$ & $\begin{array}{l}6.1 \pm 0.3 \\
(1.5)\end{array}$ & $\begin{array}{l}0.9 \pm 0.1 \\
(0.3)\end{array}$ \\
\hline Stress reticulocytes & Splenectomy & 5 & - & $\begin{array}{l}9.5 \pm 0.4 \\
(4.9)\end{array}$ & $\begin{array}{l}0.8 \pm 0.1 \\
(0.2)\end{array}$ \\
\hline Normal reticulocytes & Sham-splenectomy & 8 & $\begin{array}{l}1.7 \pm 0.1 \\
(0.7)\end{array}$ & $\begin{array}{l}5.4 \pm 0.8 \\
(0.4)\end{array}$ & $\begin{array}{l}0.7 \pm 0.1 \\
(0)\end{array}$ \\
\hline Normal reticulocytes & Splenectomy & 5 & - & $\begin{array}{l}5.1 \pm 0.5 \\
(0.1)\end{array}$ & $\begin{array}{l}0.6 \pm 0.1 \\
(0)\end{array}$ \\
\hline
\end{tabular}

Means \pm SE are shown.

* Numbers in parentheses refer to ${ }^{59} \mathrm{Fe}$ recovery after correction for organ blood ${ }^{50} \mathrm{Fe}$ (see Methods). 
celerated erythropoiesis is related to the degradation of hemoglobin from immature erythroid cells. An enlarged erythropoietic bilirubin component was generated by subjecting rats to two major hemorrhages. In some of these animals the production of early-labeled bilirubin from all sources was measured directly with glycine- $2-{ }^{14} \mathrm{C}$ (Fig. 1, Table I), while in others reticulocytes containing ${ }^{14} \mathrm{C}$-labeled hemoglobin heme were removed and transfused into unlabeled recipients with external bile drainage (Fig. 3, Table II). Comparison of the results of these experiments (Fig. 4) indicates that hemolysis of "stress" reticulocytes accounts for a major part of the rise in erythropoietic bilirubin production, a possibility already entertained by other investigators (3, $30,31)$. Findings somewhat similar to these have recently been reported (32), but in those studies reticulocyte hemolysis appeared to be maximal 6 days after transfusion, when early pigment formation would have fallen to negligible levels (Fig. 1).

The study of red cell surivival by measurement of labeled bilirubin production permits precise quantitation of the rate of degradation of hemoglobin heme and circumvents problems inherent in evaluating the specific activity of red cells labeled with ${ }^{51} \mathrm{Cr}$, ${ }^{58} \mathrm{Fe}$, or $\mathrm{DF}^{32} \mathrm{P}$. Indeed, the disappearance of ${ }^{50} \mathrm{Fe}$-labeled normal and stress reticulocytes in the present experiments (Fig. 5) was approximately twice as great as the corresponding rates of conversion of hemoglobin $-{ }^{14} \mathrm{C}$ to bilirubin $-{ }^{14} \mathrm{C}$ (Table II). Although this is compatible with loss of nonhemoglobin (e.g. siderotic) ${ }^{58} \mathrm{Fe}$ from intact reticulocytes or cell sequestration without hemolysis, the data do not provide a definite explanation for this discrepancy. Nonhemoglobin ${ }^{88} \mathrm{Fe}$ in transfused reticulocytes and in cells recovered from recipient rats was measured by comparing the specific activity of whole cells with that obtained by radioassay of crystallized hemoglobin heme; however, the data for donor cells were too variable to permit valid interpretation. Similarly, although more ${ }^{58} \mathrm{Fe}$ was recovered in the organs of rats transfused with stress as compared to normal reticulocytes (Table IV), how much of the retained ${ }^{59} \mathrm{Fe}$ may have been present in "sequestered" cells, and how much free ${ }^{58} \mathrm{Fe}$ may have escaped from these tissues could not be evaluated.

Despite its obvious advantages, potential liabilities of the bilirubin technique must also be considered. It is possible that cell damage resulted from the transfusion procedure. However, the distinct differences between stress and normal reticulocytes under identical experimental conditions (Table II, Fig. 3) must reflect significant differences in the characteristics of these cells. That the labeled bilirubin originated from sources other than red cell hemoglobin is highly improbable. Formation of early-labeled pigment from residual glycine $-{ }^{14} \mathrm{C}$ in transfused plasma was excluded by appropriate con- trol experiments. Conversion of the excess free coproand protoporphyrin present in stress reticulocytes (33, $34)$ to bilirubin (35) is also unlikely. Assuming that porphyrin levels were comparable to those found by other investigators (34) and that the specific activity of erythrocyte porphyrin was similar to that of erythrocyte heme, the total porphyrin radioactivity in a typical transfusion of stress reticulocytes amounted to less than $0.5 \%$ of the radioactivity recovered in bilirubin $-{ }^{14} \mathrm{C}$.

The findings, therefore, are consistent with the concept that erythroid stimulation leads to the formation of macrocytic reticulocytes with a shortened lifespan (36-40). They do no exclude the possibility (41) that these cells survive normally and achieve normal size through loss of hemoglobinized cytoplasm, although radioautographic studies (40) support the first conclusion. Stress reticulocytes are released prematurely from the bone marrow, and are still actively engaged in hemoglobin synthesis (42). It is therefore not surprising that there is considerable labeling of hemoglobin heme in circulating cells only $24 \mathrm{hr}$ after the administration of glycine $-{ }^{14} \mathrm{C}$ (Table II), and that, with hemolysis of whole or part of these cells, a significant fraction of this labeled hemoglobin is rapidly degraded to bile pigment (Table II, Fig. 3). As in studies based on other techniques $(38,40)$, the response to erythroid stimulation is characterized by the appearance of progressively more normal cells, and the conversion of reticulocyte hemoglobin to bilirubin declines as the interval after hemorrhage is widened (Fig. 2). This pattern probably reflects in part the selection of more normal reticulocytes after early loss of the most fragile elements within the donor rats.

It is of interest that spenectomy diminished the rise in the plateau phase of early bilirubin formation in intact bled rats (Fig. 1, Table I), but failed to affect the findings in the transfusion experiments (Table III). The formation of labeled hemoglobin was also reduced in hemorrhaged rats subjected to splenectomy (Table I), and normoblasts were readily discerned in spleens removed from bled but not normal animals. These findings all suggest that the decrease in erythropoietic bilirubin production after splenectomy was due to removal of a site of extramedullary erythropoiesis rather than to an altered rate of reticulocyte hemolysis. Indeed, the hepatic uptake of ${ }^{58} \mathrm{Fe}$ after transfusion of stress reticulocytes compensated entirely for the absence of the spleen (Table IV). However, splenectomy may have had offsetting effects upon the survival of these cells; it is well recognized that some abnormal cells are hemolyzed in the spleen, but reticulocytes also appear to undergo a period of maturation within this organ (43).

The very earliest bilirubin component, which is maximal $1-2 \mathrm{hr}$ after the administration of glycine $-{ }^{14} \mathrm{C}$ (Fig. 
1 ), is thought to originate exclusively from nonhemoglobin sources $(6,7,10)$. The rise in this initial peak after hemorrhage (Fig. 1) was therefore unexpected. In rats, labeled $\Delta$-aminolevulinic acid, a preferential precursor of extra-erythroid sources of bile pigment $(6,7$, 13), gives rise to a large narrow peak with kinetics similar to those of the initial glycine component (7); a similar peak is formed by the isolated perfused rat liver (10). In earlier experiments (7) the initial component found with glycine $-{ }^{-14} \mathrm{C}$ was generally unaffected by alterations in erythropoietic activity, but the rats in that study were of a different strain and had been subjected to less severe erythroid stimulation. The present findings may indicate that the initial sharp peak does in fact contain a potential erythropoietic component, or alternatively that factors associated with severe hemorrhage may provoke increased activity of the nonhemoglobin sources of bile pigment. An enlarged initial peak has now been described in a variety of pathologic and pharmacologic conditions affecting the liver $(11,44)$. Moreover, the fact that this peak remains discrete from the elevated plateau phase (Fig. 1) suggests an origin separate from that of the true erythropoietic fraction.

The comparison of labeled bilirubin production in intact animals and animals receiving transfusions of labeled cells (Fig. 4) serves only to approximate the contribution of reticulocyte hemolysis to the entire erythropoietic pigment fraction. On the one hand, mechanical aspects of the transfusion procedure may have exaggerated the hemolytic susceptibility of stress reticulocytes; on the other hand, the transfusion experiments measure the hemolysis only of cells in the donors' circulation at the instant of exsanguination and fail to account for cells that would have been released after this time. Within these limits, it is estimated that hemolysis of stress reticuloclytes accounts for virtually the entire rise in erythropoietic bilirubin production between 24 and $96 \mathrm{hr}$ after glycine $-{ }^{14} \mathrm{C}$ administration (Fig. $4 a$ ), but only about one-third of the total between 12 and 24 $\mathrm{hr}$ (Fig. $4 b$ ). Because of this relationship, it seems likely that reticulocyte destruction may be part of a spectrum of ineffective erythropoiesis, and that hemolysis of red cell precursors in the bone marrow may account for much of the earlier rise. It would not be surprising if this were also true of pathologic ineffective erythropoiesis. Indeed, in preliminary experiments (45), evidence for extensive reticulocyte hemolysis has been found in rats with ineffective erythropoiesis related to irondeficiency anemia (46). All of these observations support the conclusion that the erythropoietic fraction of bile pigment observed with either accelerated or abnormal red cell production is derived to a major extent from the early destruction of immature erythroid cells.

\section{ACKNOWLEDGMENTS}

The expert technical assistance of Miss Linda Lavidor is gratefully acknowledged.

This work was supported in part by Grant AM 09834 and Career Development Award AM 19600 (Dr. Robinson) from the U. S. Public Health Service.

\section{REFERENCES}

1. Robinson, S. H. 1967. Reticulocyte death: a source of early-labeled bile pigment. J. Clin. Invest. 46: 1109. (Abstr.)

2. Robinson, S. H. 1968. Erythropoietic component of early-labeled bilirubin: role of "ineffective reticulocytosis." Clin. Res. 16: 312. (Abstr.)

3. London, I. M., R. West, D. Shemin, and D. Rittenberg. 1950. On the origin of bile pigment in normal man. J. Biol. Chem. 184: 351 .

4. Gray, C. H., A. Neuberger, and P. H. A. Sneath. 1950. Studies in congenital porphyria. II. Incorporation of ${ }^{15} \mathrm{~N}$ in the stercobilin in the normal and in the porphyric. Biochem. J. 47:87.

5. Israels, L. G., J. Skanderbeg, H. Guyda, W. Zingg, and A. Zipursky. 1963. A study of the early-labelled fraction of bile pigment: the effect of altering erythropoiesis on the incorporation of $2{ }^{14} \mathrm{C}$ glycine into haem and bilirubin. Brit. J. Haematol. 9: 50.

6. Israels, L., G. T. Yamamoto, J. Skanderbeg, and A. Zipursky. 1963. Shunt bilirubin: evidence for two components. Science (Washington). 139: 1054.

7. Robinson, S. H., M. Tsong, B. W. Brown, and R. Schmid. 1966. The sources of bile pigment in the rat: studies of the "early-labeled" fraction. J. Clin. Invest. 45: 1569.

8. Robinson, S. H., R. Lester, J. F. Crigler, Jr., and M. Tsong. 1967. The early-labeled peak of bile pigment in man: studies with glycine- $C^{\mathbf{1 4}}$ and delta-aminolevulinic acid-H. N. Engl. J. Med. 277: 1323.

9. Schwartz, S., G. Ibrahim, and C. J. Watson. 1964. The contribution of non-hemoglobin hemes to the early labeling of bile bilirubin. J. Lab. Clin. Med. 64: 1003. (Abstr.)

10. Robinson, S. H., C. A. Owen, Jr., E. V. Flock, and R. Schmid. 1965. Bilirubin formation in the liver from nonhemoglobin sources. Experiments with isolated, perfused rat liver. Blood. 26: 823 .

11. Schmid, R., H. S. Marver, and L. Hammaker. 1966. Enhanced formation of rapidly labeled bilirubin by phenobarbital: hepatic microsomal cytochromes as possible source. Biochem. Biophys. Res. Commun. 24: 319.

12. White, P., A. A. Silvers, M. L. Rosher, B. C. Shafer, and W. J. Williams. 1966. Hepatic production of bilirubin and carbon monoxide in vitro. J. Clin. Invest. 45: 1085. (Abstr.)

13. Ibrahim, G. W., S. Schwartz, and C. J. Watson. 1966. Early labeling of bilirubin from glycine and delta-aminolevulinic acid in bile fistual dogs with special reference to stimulated versus suppressed erythropoiesis. Metabolism. 15: 1129 .

14. Barrett, P. V. D., M. J. Cline, and N. I. Berlin. 1966. Association of urobilin "early peak" and erythropoiesis in man. J. Clin. Invest. 45: 1657.

15. Yamamoto, T., J. Skanderbeg, A. Zipursky, and L. G. Israels. 1965. Early appearing bilirubin: evidence for two components. J. Clin. Invest. 44: 31. 
16. Robinson, S. H. 1968. The origins of bilirubin. N. Engl. J. Med. 279: 143.

17. Giblett, E. R., D. H. Coleman, G. Pirzio-Biroli, D. M. Donhue, A. G. Motulsky, and C. A. Finch. 1956. Erythrokinetics: quantitative measurement of red cell production and destruction in normal subjects and patients with anemia. Blood. 11: 291.

18. London, I. M., and R. West. 1950. The formation of bile pigment in pernicious anemia. J. Biol. Chem. 184: 359.

19. Grinstein, M., R. M. Bannerman, J. D. Vavra, and C. V. Moore. 1950. Hemoglobin metabolism in thalassemia: in vivo studies. Amer. J. Med. 29: 18.

20. James, G. W., III, and L. D. Abbott, Jr. 1961. Stercobilin $\mathrm{N}^{15}$ excretion in refractory anemia. Trans. Amer. Clin. Climat. Ass. 73: 110.

21. Robinson, S. H., T. Vanier, J. F. Desforges, and R. Schmid. 1962. Jaundice in thalassemia minor. A consequence of "ineffective erythropoiesis." $N$. Engl. J. Med. $267: 523$.

22. Ostrow, J. D., L. Hammaker, and R. Schmid. 1961. The preparation of crystalline bilirubin- ${ }^{14}$. J. Clin. Invest. 40: 1422.

23. Labbe, R. F., and G. Nishida. 1957. A new method of hemin isolation. Biochim. Biophys. Acta. 26: 437.

24. Shemin, D., I. M. London, and D. Rittenberg. 1950. The synthesis of protoporphyrin in vitro by red blood cells of the duck. J. Biol. Chem. 183: 757.

25. Keene, W. R., and J. H. Jand1. 1965. Studies of the reticuloendothelial mass and sequestering function of rat bone marrow. Blood. 26: 157.

26. Darian Smith, I., and W. J. Simmonds. 1954. The changes in cardiac output, right atrial pressure and blood volume in haemorrhagic anaemias in unanaesthetized rabbits. Aust. J. Exp. Biol. Med. Sci. 32: 241.

27. Whyte, H. M. 1956. Plasma and blood volume in anaemia and the effect of transfusion. Aust. Ann. Med. 5: 192.

28. Cartwright, G. E. 1968. Diagnostic Laboratory Hematology. Grune \& Stratton, New York. 4th edition.

29. Malloy, H. T., and K. A. Evelyn. 1937. The determination of bilirubin with the photoelectric colorimeter. $J$. Biol. Chem. 119: 481.

30. Gray, C. H., and J. J. Scott. 1959. The effect of haemorrhage on the incorporation of $\alpha-{ }^{14} \mathrm{C}$ glycine into stercobilin. Biochem. J. 71: 38

31. Berendes, M. 1959. The proportion of reticulocytes in the erythrocytes of the spleen as compared with those of circulating blood, with special reference to hemolytic states. Blood. 14: 558 .
32. Nagai, K., and E. Kakishita. 1969. Destruction of immature erythrocytes measured by bilirubin excretion. Blood. 33: 717

33. Schmid, R., S. Schwartz, and C. J. Watson. 1950. Porphyrin in bone marrow and circulating erythrocytes in experimental anemias. Proc. Soc. Exp. Biol. Med. 75: 1950.

34. Schwartz, S., and H. M. Wikoff. 1952. The relation of erythrocyte coproporphyrin and protoporphyrin to erythropoiesis. J. Biol. Chem. 194: 563.

35. Ibrahim, G. W., S. Schwartz, and C. J. Watson. 1966. The conversion of protoporphyrin- $\mathrm{C}^{14}$ to heme compounds and bilirubin in dogs. Metabolism. 15: 1120.

36. Neuberger, A., and J. S. F. Niven. 1951. Haemoglobin formation in rabbits. J. Physiol. 112: 292.

37. Berlin, N. I., and C. Lotz. 1951. Life span of the red blood cell of the rat following acute hemorrhage. Proc. Soc. Exp. Biol. Med. 78: 788.

38. Brecher, G., and F. Stohlman, Jr. 1961. Reticulocyte size and erythropoietic stimulation. Proc. Soc. Exp. Biol. Med. $107: 887$.

39. Card, R. T., and L. S. Valberg. 1967. Characteristics of shortened survival of stress reticulocytes in the rabbit. Amer. J. Physiol. 213: 566.

40. Stryckmans, P. A., E. P. Cronkite, G. Biocomelli, L. M. Schiffer, and H. P. Schnappauf. 1968. The maturation and fate of reticulocytes after in vitro labeling with tritiated amino acids. Blood. 31: 33 .

41. Ganzoni, A., R. S. Hillman, and C. A. Finch. 1969. Maturation of the macroreticulocyte. Brit. J. Haematol. 16: 119.

42. Borsook, H., J. B. Lingrel, J. L. Scaro, and R. L. Millette. 1962. Synthesis of hemoglobin in relation to maturation of erythroid cells. Nature (London). 196: 347.

43. Jandl, J. H. 1960. The agglutination and sequestration of immature red cells. J. Lab. Clin. Med. 55: 663.

44. Robinson, S. H. 1969. Increased bilirubin formation from nonhemoglobin sources in rats with disorders of the liver. J. Lab. Clin. Med. 73: 668

45. Robinson, S. H. 1969. Bilirubin production from erythropoietic and nonerythroid sources in experimental iron deficiency anemia. J. Clin. Invest. 48: 69a. (Abstr.)

46. Robinson, S. H. 1969. Increased formation of earlylabeled bilirubin in rats with iron deficiency anemia: evidence for ineffective erythropoiesis. Blood. 33: 909.

47. General Statistics, Monroe Calculating Machine Methods. 1964. Monroe International, Inc., Orange, N. J. 28. 